\title{
GROWTH PERFORMANCE AND MANAGEMENT IN MIXED FOREST STANDS
}

Heinz RÖHLE, Institute of Forest Growth and Computer Sciences in Forestry, Faculty of Environmental Sciences (Department of Forestry), Technische Universität Dresden, Germany; heinz.roehle@tu-dresden.de

In 2017, the global population stands at about 7.6 billion. Due to the medium variant of the population projections, developed by the $\mathrm{UN}$, the world population will grow to nearly 10 billion by the middle of this century. As a consequence, the worldwide demand for wood will increase. Therefore, the forest sector has to develop concepts in order to cope with the increasing demand for wood, the altering environmental conditions and the challenge of climate change.

Modified silvicultural treatment programs may contribute to solving these questions. Appropriate measures are the conversion of pure stands into mixed stands, the promotion of natural regeneration instead of artificial regeneration and the creation of structured forests consisting of indigenous or foreign tree species, which are better adapted to climate change and/or are growing faster. Mixed stands often exceed the volume as well as the biomass productivity of pure stands and increase the biodiversity of forest landscapes.

Forest simulation models are a prerequisite for the management of mixed stands. They provide enhanced opportunities of planning for forest conversion and facilitate the decision support in forest practice. These model approaches support the development of goal oriented thinning programs and make it possible to test and optimize alternative silvicultural concepts without the establishment of experimental plots. The Bavarian State Forest Enterprise (Bayerische Staatsforsten) is managing 808731 ha of forest area in the southern part of Germany. Since 2005 this enterprise is converting pure, coniferous stands (> 200000 ha of forest area) into mixed, uneven-aged forests. A simulation program (single tree simulator) is used in order to achieve this goal.

Keywords: Forest conversion, mixed stands, single tree simulators

\section{INTRODUCTION AND BACKGROUND}

It took hundreds of thousands of years for the world population to reach the first billion - and now, in 2017, the global population stands at about 7.6 billion. Due to the medium variant of the population projections, developed by the United Nations, the world population will grow to nearly 10 billion by the middle of this century (United Nations Population Fund, 2017). The rise in the world population and the economic goals of the developing countries in particular as well as the shift from fossil fuels towards renewable resources mainly in European countries will result in a significant increase in the demand for wood. This is exemplified by the global production of paper and paperboard which increased between 1980 and 2015 by $140 \%$ (FAO, 2017). And Mantau (2012) stated for Germany, that the use of wood for energy purposes in this highly industrialized country exceeds the material wood use since 2012 (total wood consumption).

In the same time, however, the worldwide area of forest cover is in decline. Furthermore, climate change and altering environmental conditions (e.g. input of nitrogen etc.) are influencing the forest ecosystems globally in different ways - sometimes in a positive and sometimes in a negative manner. Figure 1 demonstrates this impact using the example of the shift of the average site classes of Norway spruce (Picea abies) and Scots pine (Pinus sylvestris) in Saxony (Germany) during the last 130 years (Horn, 2018, in publication). Many other authors having analysed the growth patterns in European Forest came to the same findings (Pretzsch et al., 2014; Röhle, 1997; Spiecker et al., 1996). Of course, the forest sector has to cope with these challenges. In order to secure the future supply with wood from sustainably managed forests new silvicultural approaches have to be developed and realized.

\section{MATERIAL AND DATA SOURCE}

The data source for this paper comes from measurements on a lot of trial areas of the Institute of Forest Growth and Computer Sciences in Forestry, Technische Universität Dresden, and partner institutes (Chair of Forest Growth Science at Technische Universität München, Nordwestdeutsche Forstliche Versuchsanstalt Göttingen, Landeskompetenzzentrum Forst Eberswalde Brandenburg, Staatsbetrieb Sachsenforst). 
Norway spruce

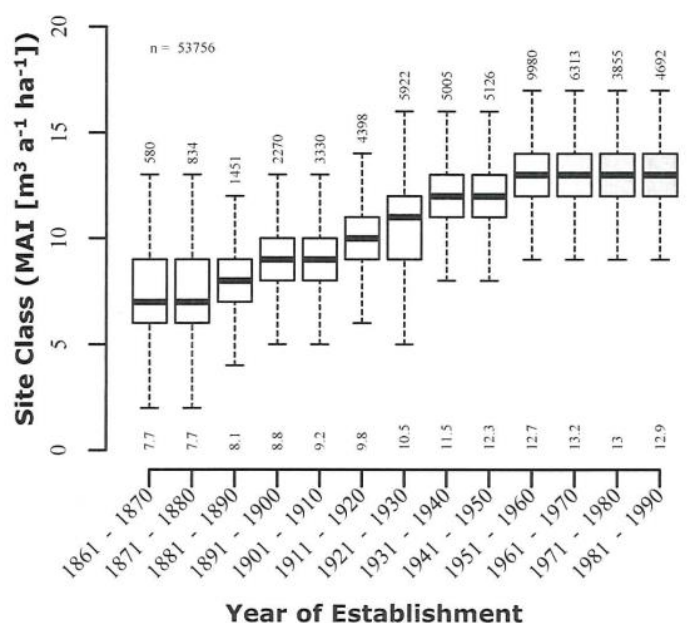

Scots pine

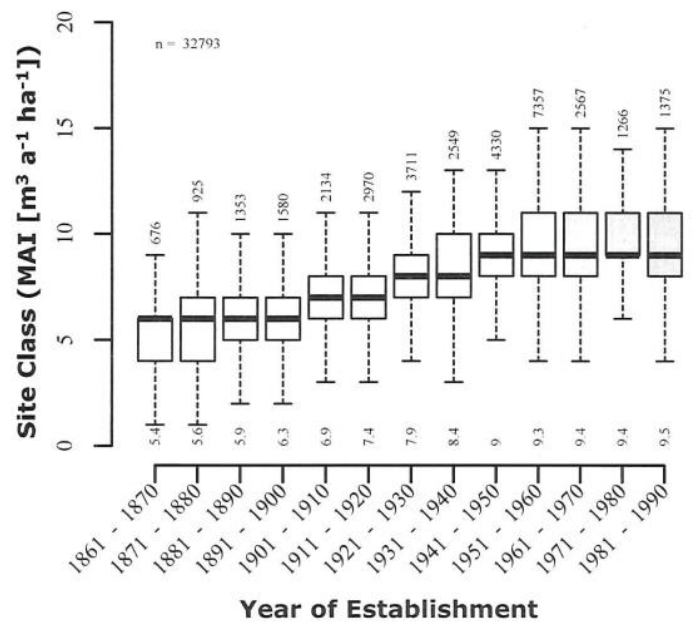

Figure 1: Shift of the average site classes (MAI $\left[\mathrm{m}^{3} \mathrm{a}^{-1} \mathrm{ha}^{-1}\right]$ at age 100) for Norway spruce and Scots Pine stands, established between 1861 and 1990 (Horn, 2018, in publication, modified). Data source: Staatsbetrieb Sachsenforst

\section{Growth Dynamics in Mixed Stands}

Diverse tree species have different genetic backgrounds (genotypes). As a consequence, they are adapted to different ecological niches and show different growth responses to the environmental conditions on the same site. If ecological niches and growth behavior of the tree species in a mixed stand are similar, the species compete more or less for the same resources. In contrast, with increasing niche differentiation in a mixed stand the interspecific competition for the resources decreases. As a consequence, the likelihood of getting access to additional resources rises and the growth performance accelerates. Therefore, mixed stands are ideally composed of tree species with differences in their ecological amplitude, in their growth behavior (fast or slow growing, flat- or deep-rooting) and in their competitive abilities (light demanding or shade tolerant, early or late successional).

Figure 2 illustrates the ecological niches of five important tree species in Europe (Norway spruce, Scots pine, European beech, sessile oak [Quercus petrea] and pedunculate oak [Quercus robur]) due to Thomasius (1991). Obviously, Norway spruce is well-adapted to a comparatively cool and wet climate, whereas the oaks profit from higher temperatures. Scots pine and European beech lie somewhere in between. And it is apparent too, that Norway spruce tolerates only a narrow temperature range between 5 and $8{ }^{\circ} \mathrm{C}$ annual mean. At the present time the annual mean temperature is about $7{ }^{\circ} \mathrm{C}$ in a lot of regions in central Europe. If climate change would lead to a rise of only $1-2{ }^{\circ} \mathrm{C}$ Norway spruce would probably disappear (or even die) slowly and the forest sector would have to think about an alternative (coniferous) tree species.

Figure 3 presents the mean annual increment (MAI) curves of three tree species with different growth performance and dynamics in an exemplary way: Willow stands for a very fast growing, light demanding (short rotation coppice) species, Scots pine for a comparatively fast growing, light demanding high forest species and beech for a slow growing, shade tolerant high forest species.

Pretzsch et al. (2013) analyzed the growth performance of oak and beech in mixture and compared it with the species' growth in pure stands. They used data from 37 long-term mixing experiments along an ecological gradient from Poland over Germany to Switzerland. They highlighted that the growth of both species was benefitted by the mixture in most cases. Merely on fertile sites an underyielding of the mixture was observed triggered by competition.

The integration of foreign tree species, which are growing faster than indigenous species, is an appropriate measure to increase the growth performance of mixed stands even further. Suitable tree species in order to achieve that goal are for example Douglas fir (Pseudotsuga menziesii), great silver fir (Abies grandis), western redcedar (Thuja plicata), sweet chestnut (Castanea sativa), northern red oak (Quercus rubra) and many others. The enormous growth performance of mixed stands is exemplified by a trial plot in southern Germany consisting of Douglas fir, Norway spruce, European beech and oak. This stand is 85 years old, the basal area amounts to $61.9 \mathrm{~m} 2$ ha-1 and the volume to $1151 \mathrm{~m} 3$ ha-1 (data source: Chair of Forest Growth Science at Technische Universität München). The stand has a multilayered structure: Douglas fir is the dominant species, spruce and oak are forming the second layer and the shade tolerant beech is growing in the understory. Figure 4 compares the height growth of Abies grandis on trial areas in northeast Germany (Horn, 2018, in publication) to the height development of the best site class (top height site index 40) of the Norway spruce yield table for southern Germany (Assmann/Franz, 1963). Figure 5 contrasts the biomass production (oven dry tons) of Abies grandis and Douglas fir to Beech on a trial area (age 32 years) in northwest Germany. The decisive superiority of Abies grandis compared to Norway spruce is clearly visible as well as the superiority of Abies grandis and Douglas fir to European beech. Finally it is worth mentioning that 1) some foreign tree species are better adapted to increasing temperatures or to decreasing precipitation (e.g. Douglas fir compared to Norway spruce) and therefore contribute to reduce the risks of 
climate change and 2) until today the differentiation in European boreal and temperate forests is comparatively low because of the species reduction in the course of the ice ages.

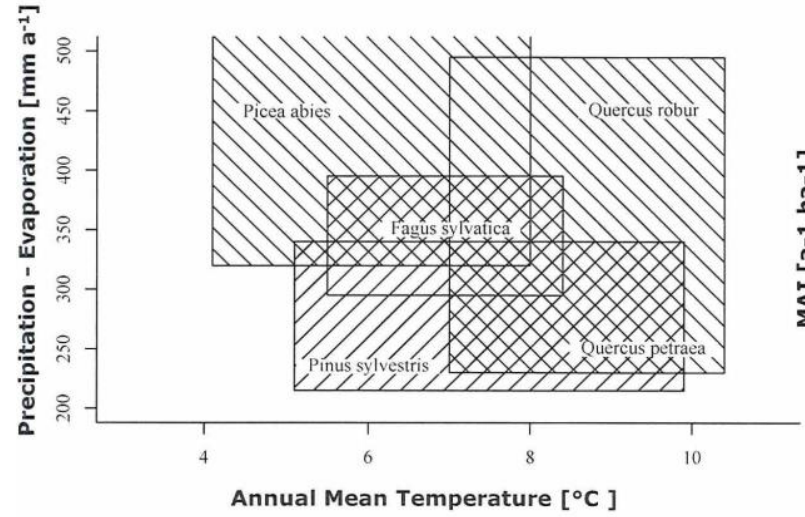

Figure 2. Ecological niches of Norway spruce, Scots pine, European beech, sessile oak and pedunculate oak in Europe (Thomasius, 1991, modified).

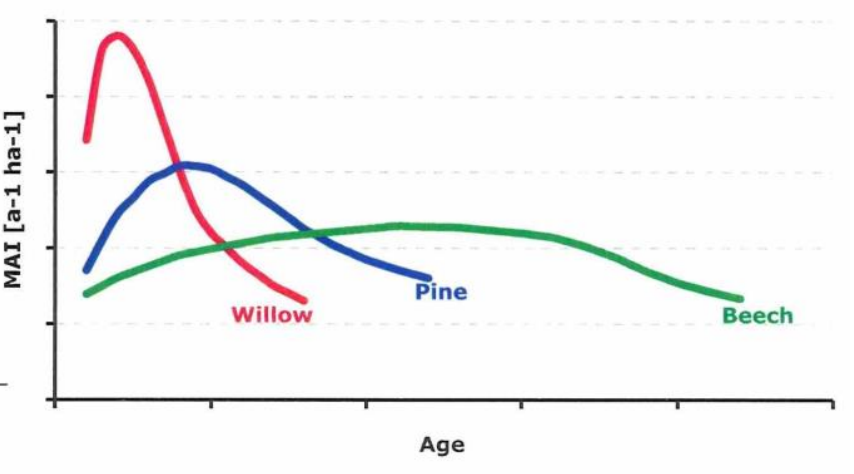

Figure 3. Exemplary mean annual increment (MAI) curves of tree species with different growth performance and dynamics.

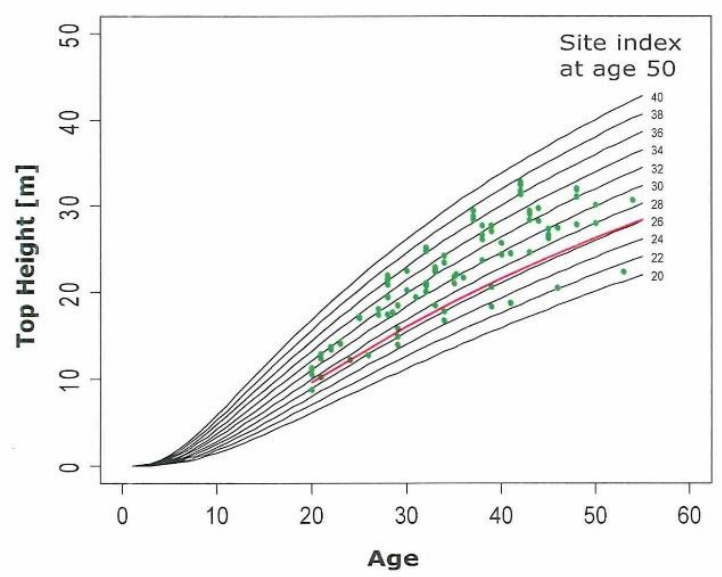

Figure 4. Trial plot data (green dots) and preliminary top height site index curves for Abies grandis in comparison to the best top height site index curve from the spruce yield table Assmann/Franz (1963, red curve). Data source: Landeskompetenzzentrum Forest Eberswalde Brandenburg

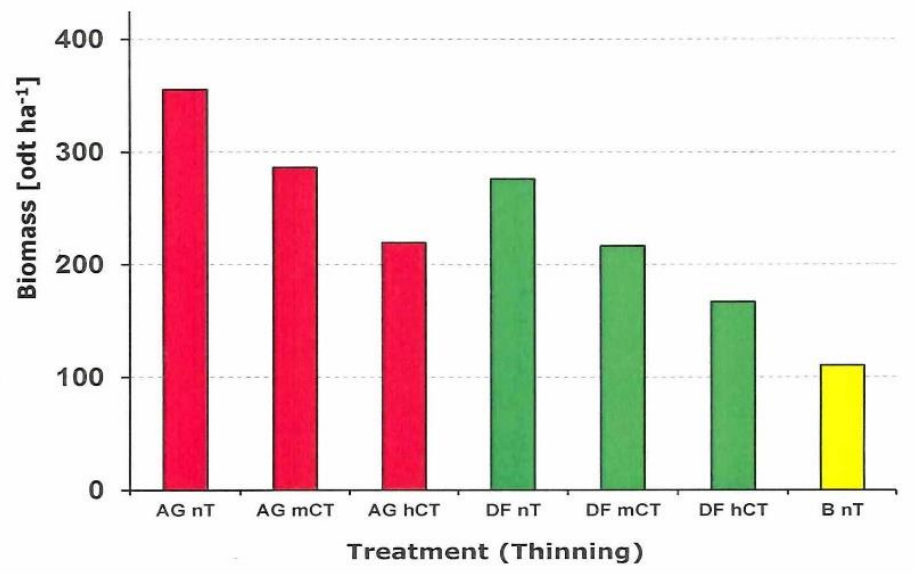

Figure 5. Biomass production (standing crop) of Abies grandis (AG),

Douglas fir (DF) and European beech (B) on a trial area in northwest

Germany. nT: no treatment, mCT: moderate crown thinning, hCT: heavy crown thinning. Data source: Nordwestdeutsche Forstliche Versuchsanstalt

\section{Management Strategies in Mixed Stands}

More than hundred years ago the forest sector in most of the European countries focused on the management of pure and even-aged stands (mainly Norway spruce or Scots pine) in order to maximize the volume production. But some decades later the problems related to large-scale monoculture conifer forestry became obvious and extensive efforts were made to address them. The conversion of pure and even-aged stands into mixed forests can be realized by integrating shade tolerant or intermediate tree species into the system. In the state of Saxony forest conversion has been an important goal since the $1990^{\text {th }}$ in order to reduce the biotic and abiotic risks associated with pure and even-aged stands. The conversion of Norway spruce and Scots pine stands was realized by advance-planting of broadleaved species like European beech, sessile oak and pedunculate oak under conifer canopies (Schröder et al., 2007). The creation of gaps in monocultures represents another appropriate measure for forest conversion (Wagner et al., 2011). Within these gaps the amount of diffuse and direct radiation varies from the center to the edge and allows different tree species to grow. Furthermore the better availability of radiation in the center of the gaps promote the establishment of fast growing and light demanding (pioneer) species, which respond with rapid height growth, whereas the reduced radiation close to the edges slows down the height increment. This growth behavior in the (naturally) regenerated layer within the gaps may lead to a species mixture and a vertical diversity regarding the tree heights. Figure 6 demonstrates, exemplified by a time series, the creation of a gap in a conifer monoculture and the development of the (naturally) regenerated broadleaved trees. Other options for the admixture of fast growing tree species into a pure (or mixed) stand are plantings in strips (e.g. in skid trails) or on the edges of stands.

The existing, traditional yield tables and other mean stem-oriented approaches cannot be applied in order to estimate the growth performance of mixed stands. This is because of the varying species composition and their different ages, the intra- and inter-specific competition, the diversity in spatial structure and the resulting variety of growth patterns in these stands. Therefore, forest simulation programs will replace the traditional yield tables in future. These simulators 
are a prerequisite for the management of uneven-aged, mixed stands and for the development and application of advanced treatment programs. Many simulation programs use competition indices for the prediction of the stand development or the single tree growth. Position-dependent model approaches (single tree simulators) decompose whole stands into a mosaic of individuals and predict the development of single trees considering the growing space and the competitive situation. These model approaches support the development of goal oriented thinning programs like selective thinning, crown thinning, group felling, target diameter harvesting etc. Furthermore they make possible to test and optimize alternative silvicultural concepts without the establishment of experimental plots and to train young forest officers.

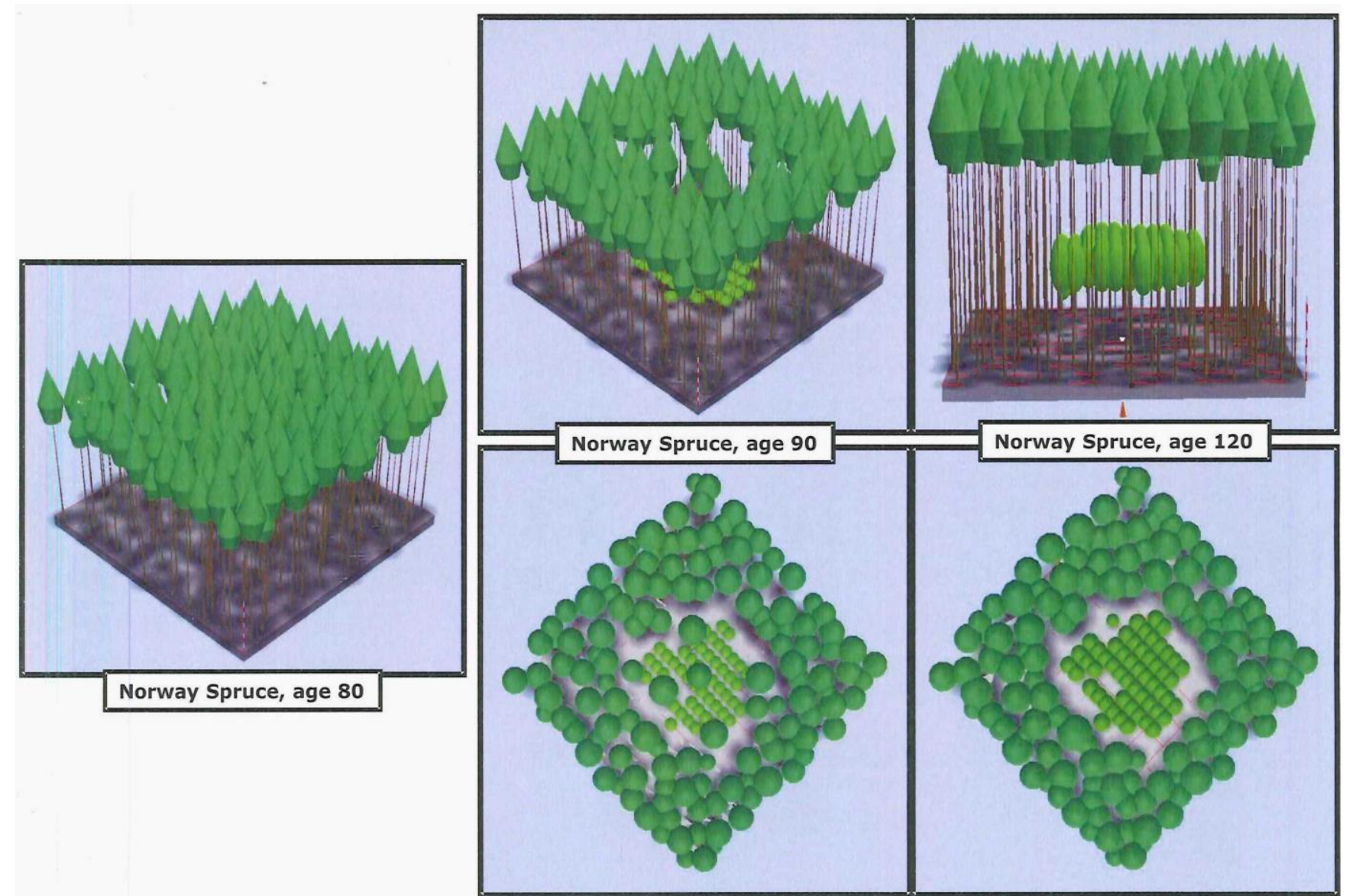

Figure 6: Exemplified creation of a gap in a Norway spruce stand and development of the regenerated broadleaved trees in a time span of 40 years, simulated with the program BWINPro (Schröder et al., 2005). Stand view (top), crown view (bottom).

\section{Example: Bavarian State Forest Enterprise (Germany)}

The Bavarian State Forest Enterprise (Bayerische Staatsforsten) in Germany is a good example for the implementation of modified silvicultural approaches and new management goals. This enterprise is managing 808731 ha of forest area in the southern part of Germany in a very successful way regarding the economic figures as well as the improvement of the environmental conditions. In 2017 the turnover amounted to 402.4 Mio. $€$ and the profit to 65.5 Mio. $€$ (Bayerische Staatsforsten, 2017). The silvicultural concept aims at converting pure, single storied and even-aged stands into mixed, uneven-aged forests. This conversion program is applied to all pure coniferous stands (> 200000 ha of forest area), mainly Norway spruce and Scots pine stands. Until today the conversion of 70000 ha of forest area is finished, 132000 ha of forest area will be converted during the next two decades. And it is worth mentioning that $66 \%$ of all conversions are realized by natural regeneration. Figure 7 informs about the planned changes in the tree species distribution (tree species distribution at the present time and desired tree species distribution). The success of the conversion program within the last decades is highlighted by the fact, that the ratio between coniferous and broadleaved species in the younger age classes was shifting towards the broadleaved trees.

\section{CONCLUSIONS - RECOMMENDATIONS}

The global population growth, the worldwide increase of the demand for wood and the altering environmental conditions (climate change etc.) are crucial challenges for the forestry.

The establishment of mixed stands increases the growth performance as well as the biodiversity of forests and may help to reduce costs as well as to increase the profit. The management of mixed stands is ideally combined with the integration of fast growing (indigenous as well as foreign) tree species and the use of natural regeneration processes. 
Simulation programs are a prerequisite for the management of mixed forests and the application of advanced silvicultural management strategies. They provide a deep insight into the growth dynamics of mixed stand and support the decision making in forest enterprises.

\section{Tree species distribution (volume) at the present time}

\section{Desired tree species distribution (area)}
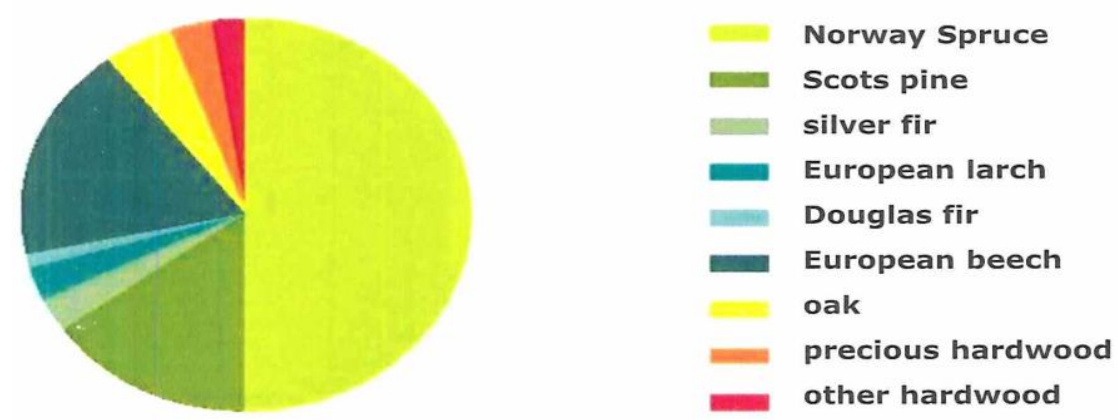

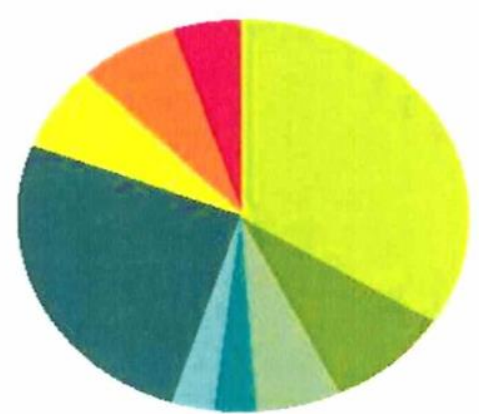

Figure 6: Desired changes in the tree species distribution by the Bavarian State Forest Enterprise in Germany (Bayerische Staatsforsten, 2017, modified).

\section{REFERENCES}

1. Assmann E., Franz F. 1963. Vorläufige Fichten-Ertragstafel für Bayern 1963 (Preliminary Yield Table for Norway Spruce in Bavaria). Institut für Ertragskunde der Forstlichen Forschungsanstalt München. 104 p. [In German]

2. Bayerische Staatsforsten 2017. Statistikband 2017 (Statistical Volume 2017), 30 p. Available at http://www.baysf.de/fileadmin/user_upload/07-publikationen/2017/BaySF_Statistikband_2017.pdf (Accessed on 11/11/2017)

3. Food and Agricultural Organisation (FAO) of the United Nations 2017: Forest products statistics. http://www.fao.org/forestry/statistics/80938/en/ (Accessed on 15/11/2017)

4. Horn H. 2018. Waldwachstumskundliche Untersuchungen zur Steigerung der Dendromasseproduktion im Spannungsfeld zwischen Plantage und Hochwald (Options for the Increase of Biomass Production in Plantations and High Forests). Doctoral dissertation TU Dresden, in publication. [In German]

5. Mantau U. 2012. Holzrohstoffbilanz Deutschland. Entwicklung und Szenarien des Holzaufkommens und der Holzverwendung 1987 bis 2015 (Timber balance Germany. Development and scenarios of timber production and timber utilization 1984 to 2015 ). Universität Hamburg, 65 p. [In German]

6. Pretzsch H., Bielak K., Block J., Bruchwald A., Dieler J., Ehrhart H.-P., Kohnle U., Nagel J., Spellmann H., Zasada M., Zingg A. 2013. Productivity of mixed versus pure stands of oak (Quercus pretraea (Matt.) Liebl. and Quercus robur L.) and European beech (Fagus sylvatica L.) along an ecological gradient. Springer Publishers. European Journal of Forest Research, Vol. 132, Iss. 2, pp. 263-280. https://doi.org/10.1007/s10342-012-0673-y

7. Pretzsch H., Biber P., Schütze G., Uhl E., Rötzer T. 2014. Forest stand growth dynamics in Central Europe have accelerated since 1870. Macmillan Publishers Limited. Nature Communications 5 (4967)

8. Röhle, H. 1997. Änderung von Bonität und Ertragsniveau in südbayerischen Fichtenbeständen (Change of Site Class and Yield Level in Norway Spruce Stands in Bavaria). Allgemeine Forst- und Jagdzeitung, Vol. 168(6/7), pp. 110-114. [In German]

9. Schröder J., Röhle H., Münder K. 2005. Simulation und Bewertung von Managementoptionen mit dem Waldwachstumssimulator BWINPro-S (Simulation and Assessment of Management Options with the Forest Growth Simulator BWINPro-S). Forst und Holz, Vol. 60, No. 10, pp. 411-415. [In German]

10. Schröder J., Röhle H., Gerold D., Münder K. 2007. Modeling individual-tree growth in stands under forest conversion in East Germany. Springer Publishers. European Journal of Forest Research, Vol. 126, pp. 459-472. https://doi.org/10.1007/s10342-006-0167-X

11. Spiecker, H., Mielikäinen, K., Köhl, M., Skovsgaard, J. P 1996. Growth Trends in European Forests. Springer Publishers https://doi.org/10.1007/978-3-642-61178-0

12. Thomasius H. 1991. Mögliche Auswirkungen einer Klimaveränderung auf die Wälder in Mitteleuropa (Impacts of Climate Change on the Forests in Central Europe). Forstwissenschaftliches Centralblatt, Vol. 110(1), pp. 305-330. https://doi.org/10.1007/BF02741264 [In German]

13. United Nations Population Fund 2017. World population trends. Available at http://www.unfpa.org/world-population-trends (Accessed on 11/11/2017)

14. Wagner S., Fischer H., Huth F. 20011: Canopy effects on vegetation caused by harvesting and regeneration treatments. Springer Publishers. European Journal of Forest Research, Vol. 130, pp. 17-40. https://doi.org/10.1007/s10342-010-0378-z 